\title{
The Performance of Goverment Official at The Demography and Civil Department in Situbondo Observed by Competence, Motivation and Commitment Aspect
}

\author{
Rosida Salijana \\ Population and Civil Registration Agency, Situbondo Regency \\ rosidasalijana27@gmail.com
}

\author{
Akhmad Toha \\ University of Jember \\ toha.fisip@unej.ac.id
}

\author{
Selfi Budi Helpiastuti \\ University of Jember \\ selfibudihelpiastuti@unej.ac.id
}

\begin{abstract}
The pre-survey process showed that the report on performance was not optimal and human resources in the Department of Population and Civil Registry were inadequate and Minister of Administrative Reform and Bureaucratic Reform No. 38 of 2017 concerning the Competency Standards of the Position of the State Civil Apparatus which requires the State Civil Apparatus that has the competence, discipline, participatory, motivative and commitment in carrying out the performance of public services, then this study takes focus on the influence of competence, motivation and commitment to the performance of the State Civil Apparatus in the Population and Civil Registry Office of Situbondo Regency. This study aims to find out and analyze the competence, motivation, and commitment of employees to the performance of the Government of Situbondo Regency. This type of study is a quantitative study using a saturated sample of 29 State Civil Apparatuses in the Situbondo Regency Population and Civil Registry Office. Data collection techniques used in the study through surveys using questionnaires, interviews and documentation. Data from the subsequent studies were analyzed using multiple linear regression. Based on the results of the study it can be concluded that: 1). Partially, competence and commitment have a positive and significant effect on the performance of the State Civil Apparatus in the Population and Disability Service Office of Situbondo Regency. While motivation has a positive effect, but it is not significant on the performance of the State Civil Apparatus in the Population and Civil Disability Office of Situbondo Regency, and 2). Simultaneously the variable X together on the performance of the State Civil Apparatus has different results. Where the competency and commitment variables have a positive and significant effect, whereas motivation only has a positive effect.
\end{abstract}

Keywords: Performance, Competence, Motivation, Commitment

\section{INTRODUCTION}

The State Civil Apparatus is a resource that has an important meaning for the government to mobilize and manage other resources effectively and efficiently according to the real needs of the organization and society. Constitution (UU) 5 of 2014 concerning State Civil Apparatus Article 1 Paragraph 1 states that the State Civil Apparatus is citizens who have fulfilled the specified requirements, appointed by 
authorized officials and assigned tasks in an office or assigned to other countries, and paid according to the applicable laws and regulations.

Thus a State Civil Apparatus must be neutral from the influence of groups and political parties and not discriminatory in providing services to the community. The State Civil Apparatus is demanded to always provide services to the community in a professional, honest, fair and equitable manner in carrying out the duties of the state, government and development. To be able to run services optimally, the principle of merit system must be implemented.

Merit system is an approach that emphasizes the management of the State Civil Apparatus by basing the suitability between the expertise of employees with the qualifications of their positions. Mismatch between employee competencies and job qualifications is a major problem and for the cause of the lack of professional State Civil Apparatuses that have an impact on their performance.

Ashari (2010: 4) states that the need for empowerment to solve the problems of government employees that are common, such as:

1. Spoil system practices and incompetence in employee recruitment and selection systems.

2. Staffing structures, especially those concerning quality and quantity and distribution that are not ideal.

3. The level of efficiency and effectiveness and employee performance that is not optimal.

4. Employee career systems and patterns that are unclear, transparent, and competitive, and

5. The level of discipline, work ethic, and work culture of employees is still low.

The poor management of the State Civil Apparatus has also been exacerbated by the bureaucracy politicization in the realm of administration, namely the intervention of political officials in the appointment of career positions of the State Civil Apparatus. As Damayanti (2009: 12) states that in the history of the administration of the Indonesian government is laden with bureaucratic politicization, where the position of the bureaucracy cannot be neutral towards the political forces that play in government. The appointment of the position of the State Civil Apparatus is chosen and promoted not based on a merit system but rather caused by politicization of the bureaucracy, ven takedown or demotion can not be separated from the nuances of bureaucratic politicization.

Efforts to realize a state civil service that is professional and free from political interests by providing good, fair and inclusive services, is not just a match with the assignment. State Civil Apparatus are also required to have the ability and expertise in translating the aspirations of the people in each of their service programs. Minister of Administrative Reform and Bureaucratic Reform No. 38 of 2017 concerning the Competency Standards of the Position of the State Civil Apparatus reinforces the severe opinion of the previous experts above about the Merit system. Wherein in the PP stated that the Management of the State Civil Apparatus is organized based on a merit system, where in the career development of the State Civil Apparatus is carried out on the basis of qualifications, competencies, performance appraisal, and the needs of Government Agencies by considering integrity and morality. he competencies in question include: 
1. Technical competence as measured by the level of educational specialization, functional technical training and technical work experience;

2. Managerial competence as measured by the level of education, structural or management training, and leadership experience; and

3. Socio-cultural competence as measured by work experience related to plural society in terms of religion, ethnicity, and culture so as to have a national outlook.

In the placement of the State Civil Apparatus in a certain government structure or position, it should be noted is to place the right person in the right place, by considering the educational background, rank / class, years of service, as well as other conditions in accordance with applicable regulations. It aims to make the capabilities and expertise possessed by a State Civil Apparatus in accordance with the demands of the task or position, so that existing human resources will be productive and high achievers which in turn will be able to improve performance in an organization as a whole.

In order to improve the competency standard of the position of the State Civil Apparatus, then the State Minister for the Utilization of the State Apparatus and Bureaucracy Reform issued a Regulation of the Minister of State for the Utilization of the State Apparatus and Bureaucratic Reform No. 38 of 2017 concerning the Competency Standards of the Position of the State Civil Apparatus with a emphasis on competence, motivation and commitment which has been the pathology of bureaucrats that has not been resolved. As stated by Deputy of Human Resources Apparatus of the Ministry of PANRB Setiawan Wangsaatmaja in the socialization event PP No. 30/2019 and the enrichment of the substance of the PANRB Candy Draft on the PNS Performance Management System in Jakarta states that the issue of performance management lies in competence, motivation and commitment of the State Civil Apparatus so it needs to be managed properly (Ministry of PANRB, 16 October 2019).

In order to strengthen the Ministerial Regulation, the President of the Republic of Indonesia on May 9, 2019 when opening the National Musrenbang gave directions to all regional heads that they were required to place an official in the right position according to their competence. Competence can be seen from the mastery of technology and conceptual abilities possessed, so that he deserves to be promoted in certain positions.

The call for regulation and direction of the President above, in practice seems to have not been carried out optimally, as happened in the Situbondo Regency Population and Civil Registry Office from the initial observation results of the study showed that the placement of the State Civil Apparatus in certain positions was still not in accordance with the mechanism of the merit system, that is, many officials whose educational backgrounds do not match what is needed by the service.

The impact of the placement of officials not based on the mechanism of the merit system, the performance of the Office of Population and Civil Registration in Situbondo Regency is not optimal. Where the implementation of activities in the agency is only in the range of 90 percent from the initial plan of 100 percent, as in the table below: 
Table 1 Main Performance Indicators and Sectors in the Population and Civil Registry Office of Situbondo Regency Situbondo Regency

\begin{tabular}{|c|c|c|c|}
\hline No. & Target & Plan & Implementation \\
\hline 1. & $\begin{array}{c}\text { Increasing the quality of } \\
\text { population services }\end{array}$ & $100 \%$ & $88 \%$ \\
\hline 2. & $\begin{array}{c}\text { Increased ownership of } \\
\text { population documents }\end{array}$ & $100 \%$ & $92 \%$ \\
\hline
\end{tabular}

Source: 2018 Population Service and Civil Registry Performance Report

The table above shows that the activities in the Situbondo Regency Population and Civil Registry Office are currently included in the category of unsuccessful policy implementation. According to Hoogwood and Gunn (2008: 61-62), an unsuccessful implementation implies that the policy has been implemented according to plan, but considering the unfavorable internal and external conditions cause the policy to be unsuccessful.

Based on the opinion of Hoogwood and Gunn above, internal conditions (read: State Civil Apparatus skills) that led to the implementation of activities in the Situbondo Regency Population and Civil Registry Office were not running optimally. This condition is an initial phenomenon of gaps or gaps that can be followed up with a study of: Influence of Competence, Motivation and Commitment on the Performance of the State Civil Apparatus in the Population and Civil Registry Office of Situbondo Regency.

\section{STUDY FORMULATION}

Based on the above background, the formulation of the problems in this study are as follows:

1. Partially is there a positive and significant influence of competence, motivation and competence on the performance of the State Civil Apparatus in the Population and Civil Registry Office of Situbondo Regency?

2. Simultaneously is there a positive and significant influence of competence, motivation and competence on the performance of the State Civil Apparatus in the Population and Civil Registry Office of Situbondo Regency?

\section{STUDY OBJECTIVE}

Based on the problem formulation, the objectives of this study are as follows:

1. Analyzing partially the effect of competence, motivation and competence on the performance of the State Civil Apparatus in the Population and Civil Registry Office of Situbondo Regency.

2. Analyzing simultaneously the effect of competence, motivation and competence on the performance of the State Civil Apparatus in the Office of Population and Civil Registry of Situbondo Regency. 


\section{CONCEPTUAL FRAMEWORK}

\section{A. Performance Factors}

Some theories explain the factors that affect a person's performance either as an individual or as an organization that exists and works in an environment. As individuals, everyone has physical and non-physical characteristics and characteristics. And humans who are in the environment, the existence and behavior can not be separated from the environment where they live and work.

The performance of an employee will be good, if the employee has high expertise, willingness to work, the existence of proper rewards and hopes for the future (Prawirosentono, 2006). According to Ilyas (2001), theoretically there are three groups of variables that affect work behavior and performance, namely: individual variables, organizational variables and psychological variables. The three groups of variables affect the work group which ultimately affects the performance of the personnel. Behavior related to performance is related to work tasks that must be completed to achieve the goals of a position or task.

Factors that affect performance according to experts are as follows: First, performance is influenced by competence and motivation as stated by Hersey and Blanchard (1993) stating one's own performance in actual work depends on a combination of ability and motivation on each employee. Meanwhile, according to George Klemp (2016: 143), said that competence and motivation are characteristics that underlie someone who produces effective work and / or superior performance. Hersey and Blanchard's opinion is reinforced by Mangkunegara (2006: 13) which states that a person's performance is influenced by two things, namely ability and motivation.

Second, performance is influenced by Competence and Commitment as stated by Hellriegel, Jackson and Slocum (2005: 4), competence and commitment are a combination of knowledge, skills, behaviors and attitudes that contribute to performance effectiveness. Third, performance is influenced by commitment and motivation as stated by Quirin, Donel, O'Bry (2001) states that commitment and motivation have a positive effect on performance, because someone makes an agreement (attachment), both to oneself and to others as reflected in certain actions / behaviors carried out voluntarily or forced. While motivation is an impulse that causes someone to do an action to achieve certain goals.

Based on the description above, the factors that influence performance consider the work that is generated, cooperation, initiative, knowledge, attendance, and loyalty in order to be able to provide effective services for the community.

\section{B. Competence}

Etymologically competency is defined as the ability needed to do or carry out work that is based on knowledge, skills and work attitudes. So that it can be formulated that competence is defined as the ability of someone who can be observed including the knowledge, skills and work attitudes in completing a job or task in accordance with established performance standards. $\mathrm{n}$ the meaning of language, competency standards are formed on the word standard and competency. Standards are defined as agreed "measures", while competencies have been defined as the ability of an observable person to include knowledge, skills and attitudes in completing a job or task in accordance with established performance standards.

According to Spencer (2007) competence is the ability to carry out work or tasks based on skills and knowledge and is supported by work attitudes determined by 
the job including knowledge, skills, and attitude. Zwell (2007) states that the factors of ability are twofold, namely: 1). Physical ability, namely the ability to move according to the condition of stamina, strength and biological characteristics (knowledge and attitude).2). Intellectual ability is the ability in activities related to mental activity (Skill). Meanwhile, according to Langen (2008) competence is the knowledge and skills as well as the ability of a person to perform cognitive, effective and psychomotor behaviors by actually applying them in accordance with established performance standards.

Meanwhile according to Wibowo (2012) competence is the ability to carry out work or tasks based on skills and knowledge and is supported by work attitudes determined by the job. Competence shows the knowledge, skills and certain attitudes of a profession in certain characteristics of expertise, which characterize a professional.

Competence literally comes from the word competence, which means ability, authority and ability. In terms of etymology, competence means aspects of excellence, expertise from the behavior of an employee or leader who has a good knowledge, behavior and skills. Characteristics of competencies is something that becomes part of personal character and becomes part of one's behavior in carrying out a work task.

\section{Motivation}

Motivation comes from the Latin word movere which means encouragement or move. Theoretically according to Herzberg (1979) states that motivation is the process of arousing, directing and stabilizing the behavior of a goal. Meanwhile, George (2005) stated that motivation is to cause, channel and support human behavior, so that they want to work actively and enthusiastically to achieve optimal results based on material encouragement, inner satisfaction) and challenges.

As for Bernhart (2014) see motivation as something in the person of a person who strongly encourages the desire to carry out the work seriously in order to achieve goals and objectives. Furthermore, Westerman (1997: 123) interprets motivation as a series of processes that encourage a person's behavior and lead him to the achievement of several goals., or in a shorter way that encourages someone to do something that must be done voluntarily well. Meanwhile, according to Djaali (2008) motivation is the process of arousing, directing and strengthening the behavior of a goal. Motivation is the background of individuals doing to achieve certain goals.

\section{Competence}

Organizational Commitment is most often defined, namely: 1. A strong desire to remain a member of a particular organization; 2 . The desire to try hard according to the wishes of the organization; 3. Certain beliefs, and acceptance of organizational values and goals. In other words, this is an attitude that reflects employee loyalty to the organization and the ongoing process whereby members of the organization express their concern for the organization and success and continuous progress, Luthans (2006: 249). According to Munandar, (2004: 75), states that organizational commitment is the nature of an individual's relationship with the organization by showing the following characteristics: 1. Affective Commitment (Komitmen Afektif), 2. Continuance Commitment (Komitmen Berkelanjutan), and 3. Normative Commitment (Komitmen Normatif).

Luthans (2006:249states that commitment is an attitude that reflects employee loyalty to the organization, including affective commitment, continuance commitment and normative commitment and an ongoing process whereby members of the organization express their concern for the organization and continued success and progress. 
Luthans' opinion has the support of Griffin (2004: 15) which states that organizational commitment is an attitude that reflects the extent to which an individual knows and is bound to his organization.

According to Robbins (2001: 140), stating commitment to an organization is defined as a situation where an employee sided with a particular organization and its objectives, and intends to maintain membership in that organization. Robbins views organizational commitment as one of the work attitudes that is influenced by affective, normative and sustainable attitudes. As according to Greenberg and Baron, (2000: 184) the consequences of commitment, namely: First, commited employees are less likely to withdraw or committed employees are less likely to resign. The greater the employee's commitment to the organization, the less likely it is to resign. This commitment encourages people to continue to love their work and be proud when they are there. second, commited employees are less willing to sacrifice for the organization: Committed employees are willing to sacrifice for the sake of the organization or committed employees show high awareness to share and sacrifice needed for the survival of the agency.

\section{STUDY METHOD}

The method in this study uses the quantitative type of this study is a quantitative study using a saturated sample of 29 State Civil Apparatuses in the Situbondo Regency Population and Civil Registry Office. Data collection techniques used in the study through surveys using questionnaires, interviews and documentation.

\section{STUDY RESULTS AND DISCUSSION}

A. Study Analysis Results

The results of the inferential analysis in this thesis are divided into 2 (two) parts, namely the partial influence on each variable X on the performance of the State Civil Apparatus in the Population and Civil Registry Office of Situbondo Regency, and the simultaneous influence of variable $X$ together on the performance of the State Civil Apparatus in the Situbondo Regency Population and Civil Registry Service, with the following explanation:

1. Partial Influence of Competence (Xl) on Performance (Y) of the State Civil Apparatus in the Population and Civil Registry Office of Situbondo Regency

The results of the study indicate that the partial influence on the variable $(\mathrm{Xl})$, namely competence consisting of knowledge, skills and attitude of the State Civil Apparatus has a positive and significant influence in improving the performance of the State Civil Apparatus in the Office of Population and Civil Disability Situbondo Regency, as stated in the table below: 
Table 2 Results of Analysis of the Relationship of Competence Variables to Performance

\begin{tabular}{|c|c|c|c|c|c|c|}
\hline \multirow{2}{*}{\multicolumn{2}{|c|}{ Model }} & \multicolumn{2}{|c|}{ Unstandardized Coefficients } & $\begin{array}{l}\text { Standardized } \\
\text { Coefficients }\end{array}$ & \multirow[b]{2}{*}{$t$} & \multirow[b]{2}{*}{ Sig. } \\
\hline & & $B$ & Std. Error & Beta & & \\
\hline & $\begin{array}{l}\text { (Constant) } \\
\text { competence }\end{array}$ & $\begin{array}{c}19.283 \\
7.516\end{array}$ & $\begin{array}{c}4.435 \\
.970\end{array}$ & .541 & $\begin{array}{l}4.348 \\
7.746\end{array}$ & $\begin{array}{l}.000 \\
.000\end{array}$ \\
\hline
\end{tabular}

Source: Study results, 2019

Based on table 2 above, it can be seen from the value of the probability or knowledge or belief that an event will be valid or has occurred 0,000 less than the alpha value $(\alpha=1 \%)$.

2. Partial Influence of Motivation (X2) on Performance (Y) of State Civil

Apparatus in the Population and Civil Registry Office of Situbondo Regency

The results of the study show that the partial effect on the variable (X2) is motivation which apparently has no significant impact or only has a positive effect on the performance of the State Civil Apparatus in the Population and Civil Disability Office of Situbondo Regency, as noted in the table below:

Table 3 Results of Analysis of the Relationship of Motivational Variables to Performance

\begin{tabular}{|cc|c|c|c|c|c|}
\hline \multirow{2}{*}{} & \multicolumn{3}{|c|}{$\begin{array}{c}\text { Standardized } \\
\text { Coefficients }\end{array}$} & & \\
\cline { 2 - 4 } & Model & $B$ & Std. Error & Beta & $t$ & Sig. \\
\hline l l Constant) & 19.283 & 4.435 & & 4.348 & .000 \\
& Motivation & -1.272 & 1.222 & -.092 & -1.041 & .308 \\
\hline
\end{tabular}

Source: Study results, 2019

Based on the table above, it can be seen from the probability value or knowledge or belief that an event will be valid or has occurred 0.308 greater than the alpha value ( $\alpha$ $=1 \%, 5 \%$ and $10 \%$ ).

3. Partial Influence of Commitment (X3) on Performance (Y) of the State Civil Apparatus in the Population and Civil Registry Office of Situbondo Regency The results of the study show that the partial effect on the variable (X3), namely commitment consisting of affective commitment, continuance commitment, normative commitment has a positive and significant relationship affecting performance, as illustrated in the table below this:

Table 4 Results of Analysis of the Relationship of Commitment Variables to Performance

\begin{tabular}{|c|c|c|c|c|c|}
\hline \multirow[b]{2}{*}{ Model } & \multicolumn{2}{|c|}{$\begin{array}{c}\text { Unstandardized } \\
\text { Coefficients }\end{array}$} & $\begin{array}{c}\text { Standardized } \\
\text { Coefficients }\end{array}$ & \multirow[b]{2}{*}{$\mathrm{t}$} & \multirow[b]{2}{*}{ Sig. } \\
\hline & $B$ & Std. Error & Beta & & \\
\hline$($ Constant $)$ & 19.283 & 4.435 & & 4.348 & .000 \\
\hline $\begin{array}{c}\text { Commitmen } \\
t\end{array}$ & 5.677 & 1.012 & .586 & 5.610 & .000 \\
\hline
\end{tabular}

Source: Study results, 2019

Based on the table above, a positive and significant relationship to commitment to performance can be seen from the value of the probability or knowledge or belief that an event will take place or has occurred at 0,000 less than the alpha value $(\alpha=1 \%)$. 


\section{Simultaneous Effect of Variable X Together on the Performance of the State Civil Apparatus in the Population and Civil Registry Office of Situbondo Regency}

After discussing the partial influence in the previous sub-chapter, then in this subchapter on the simultaneous influence the writer conducts a discussion of the effect of variable X (competence, motivation and commitment) jointly on the performance of the State Civil Apparatus can be explained that the factors that affect the performance of the State Civil Apparatus in the Population and Civil Registry Office of Situbondo District can be analyzed using multiple regression analysis, to provide a detailed description of the relationship of competition factors, motivation and commitment to the performance of the State Civil Apparatus and based on the feasibility of a regression model of aspects that exist in competencies, such as knowledge, skills, attitude, and financial aspects, inner satisfaction, challenge (challenges) that exist in motivation as well as aspects of affective commitment (affective commitment), continuance commitment (normative commitment), normative commitment (normative commitment) that exists on these commitments as a whole are worthy of testing using the regression model analysis, as listed in the table below:

Table 5 Feasibility of Regression Models

\begin{tabular}{|c|c|c|c|c|}
\hline Model & $R$ & R Square & Adjusted R Square & Std. Error of the Estimate \\
\hline 1 & $.966^{\mathrm{a}}$ & .933 & .925 & 1.791 \\
\hline
\end{tabular}

Source: Study results, 2019

Furthermore, the results of the regression analysis using SPSS for Windows Release 0 note that the R-Square value shows 0.933 . Thus the factors of competition, motivation and commitment can provide changes to performance by 93 percent, with another 7 percent influenced by other variables besides competition, motivation and commitment, as the table below:

Table 6 Simultaneous Results in Regression Analysis

\begin{tabular}{|c|c|c|c|}
\hline Variabel & Koefisien & T-Statistik & Probabilitas \\
\hline (Constant) & & 4.348 & $0.000^{*}$ \\
\hline Kompetensi & 0.541 & 7.746 & $0.000^{*}$ \\
\hline Motivasi & -0.092 & -1.041 & 0.308 \\
\hline Komitmen & 0.586 & 5.610 & $0.000^{*}$ \\
\hline R-Square & \multicolumn{3}{|c|}{0,933} \\
\hline Adjusted R-Square & 0,925 \\
\hline
\end{tabular}

${ }^{*}$ Signifikan $\alpha=1 \%$

Source: Study results, 2019

Based on the simultaneous results table in the regression analysis (competition, motivation and commitment) on the performance of the State Civil Apparatus in the Office of Population and Civil Disability, Situbondo District can be drawn a common thread that competence and commitment have a positive and significant effect on the performance of the State Civil Apparatus in the Population and Civil Disability Service Situbondo Regency. While motivation does not have a significant effect and only has a positive effect on the performance of the State Civil Apparatus in the Population and Disability Service Office of Situbondo Regency.

\section{B. Discussion of Hypothesis Testing Results}

The presentation in the sub-section on the discussion of the results of this hypothesis testing conducted an in-depth analysis related to competence, motivation and commitment to the performance of the State Civil Apparatus in the Population and 
Civil Registry Office of Situbondo Regency, reviewed with previous research hypotheses, and relevant theories as reinforcement of the results of data analysis. study. The discussion related to this is described in 4 (four) sub-chapters covering the discussion of the results of testing the hypothesis simultaneously and partially, as follows:

\section{Discussion on the Effect of Competence on the Performance of the State Civil Apparatus in terms of the Study Hypothesis and Relevant Theory}

The study hypothesis $(\mathrm{Hl})$ states that competence has a positive and significant effect on the performance of the State Civil Apparatus. The hypothesis of this study is in line with the opinion of Spencer (2007), which states that competence is knowledge and skills as well as the ability of a person to perform cognitive, effective and psychomotor behavior by actually applying it in accordance with established performance standards.

The results of the study showed that it was in line with the study hypothesis $(\mathrm{Hl})$ and Spencer's opinion that competence had a significant positive and significant effect, when compared to the commitment variable with the value of the statistical sample t-test, 7,746. The reason for the high positive level and significance of competence on the performance of the State Civil Apparatus is because in each aspect of the competency is considered important by the majority of respondents with detailed explanation as follows: first, The knowledge component consisting of understanding, knowledge and policy making is understood by the majority of respondents as an important and fundamental component that must be possessed by the State Civil Apparatus in optimizing its competence. The results of this study are in line with the view of Reber (2010) which states that knowledge is a collection of information that is owned by a person or group, or a particular culture. While knowledge in general according to Reber (2010) are mental components that result from all any process, whether born from innate or achieved through experience. Based on the results of the studies and expert opinions above, a common thread can be drawn that knowledge is a collection of information obtained from experience that makes the State Civil Apparatus know what to do.

Second, the skill component consisting of the ability to provide services is an important thing that is owned by every State Civil Apparatus, because according to the majority of respondents the skill (skill) of the State Civil Apparatus is one of the factors in achieving success in achieving organizational goals. The purpose of work skills is to be able to facilitate a job in completing each job effectively and efficiently without any difficulties so that it will produce a good employee performance (Kadarisman, 2001: 53). The purpose of developing the State Civil Apparatus is to improve the effectiveness of the work of the State Civil Apparatus in achieving the results of work that have been determined. Improvement of work effectiveness can be done by improving the knowledge of the State Civil Apparatus, employee skills and the attitude of the State Civil Apparatus itself towards its duties. Therefore, skill development must be endeavored continuously in the development of the State Civil Apparatus.

Third, the attitude component consists of work suitability, compliance with values or norms, and the ability to cooperate. This is in line with Berkowitz's opinion (2013) which states that attitude is an evaluation or reaction of feelings of support or partiality or a feeling of not supporting or not supporting in favor of the object. Meanwhile, according to Thurstone (2004), attitude as a level of positive or negative tendencies associated with psychological objects, a positive attitude if he likes 
otherwise the person said to have a negative attitude towards psychological objects if he does not like it. According to Lapierre (2006) defines attitude as a pattern of behavior, tendencies, or anticipatory loneliness, predisposing to adjust to social situations, or simply attitude is a response to social stimuli that have been conditioned. In a review of the attitudes category, the attitude of a person of the State Civil Apparatus towards what he does is influenced by the values held or behind the Civil Apparatus as his life experience. The State Civil Apparatus that has been embedded and crystallized certain values in mental or personality, of course in dealing with and responding to something will be colored by the values that he believes, and this is the view of the majority of respondents in this study.

Based on a detailed explanation of the components in competence, namely knowledge, skills and attitudes, it is not surprising when it becomes the highest value in this study. Because the majority of the State Civil Apparatus considers competence as fundamental and important in realizing the optimal performance of the State Civil Apparatus.

On the other hand, the results of the author are also in line with several previous studies put forward by: First, a previous study conducted by Edy Sujana (2012) which states that competence has a positive and significant effect on organizational commitment. Secondly, a previous study conducted by Rokhilah and Susetyo Darmanto (2014) stated that the competency variable could have an influence on the performance of family planning instructors in Pemalang Regency. Thus competence is able to improve the achievement or participation of family planning in Pemalang Regency.

Third, Djumar Soewito, Kusmayadi, and Arie Andarie (2017) on the Effect of Employee Competence on Employee Performance at the Sempaja Selatan District Office in North Samarinda District. This study concludes that: (1). Based on the total score of the $\mathrm{X}$ and $\mathrm{Y}$ variables, the employees at the Sempaja Selatan Kelurahan Office, Samarinda Utara District have quite good competence with good performance.

\section{Discussion on the Effect of Motivation on the Performance of the State Civil Apparatus in terms of the Study Hypothesis, Relevant Theory}

According to Herzberg (1979), making good policies on employees encourages employees to work more optimally, such as by providing incentives in the form of work performance benefits and overtime pay. In the study hypothesis (H2) stated that motivation has a positive and significant effect on the performance of the State Civil Apparatus.

The results of the study show different things from the study hypothesis (H2). Where the motivation variable is only positively influential with the $t$ test value of the statistical sample is only -1.041. The cause of motivation is only a positive effect for several reasons, including: First, the financial component (material) which consists of salary and reward cannot be interpreted positively by the State Civil Apparatus as a motivation in improving its performance. Salary is actually a compensation for the amount of performance performed (Soekidjo, 2003: 153). However in practice, the salary received by the State Civil Apparatus in the Office of Population and Civil Disability Situbondo Regency is interpreted not as compensation, but as rights. This means that the good or poor performance they do the salary they receive is the same or there is no increase.

Secondly, the inner satisfaction component, that in its performance many State Civil Apparatuses are not oriented toward inner satisfaction, so the performance is less 
motivated and that happens to the majority of respondents in this study. The results of the study of motivation only have a positive effect on the performance of the State Civil Apparatus actually criticizing some of Oliver's (1997) opinions, which states that inner satisfaction is a motivation in employee performance.

Third, the component of the challenge (challenge), that in its performance many State Civil Apparatuses are working as a routine, so they are less challenged to provide innovation in public services. Whereas policy innovation is important in improving the performance of the State Civil Apparatus. According to Metcalfe (1995), innovation is a contribution jointly and individually in the development of public services according to the will of the public

The overall competency component above, mainly the financial (material) component which consists of salary and reward does not have a significant or positive effect on the performance of the State Civil Apparatus in the Population and Civil Disability Office of Situbondo Regency. Because they claim that salaries and rewards will still be given in full by the Situbondo Regency Government even though their performance is not optimal.

Because the Department of Population and Civil Disability of Situbondo Regency is a public institution that has guaranteed the rights of all its employees, so the motivation variable is considered to have no significant effect and only has a positive influence on improving the performance of the State Civil Apparatus in the Situbondo Civil Population and Disability Office.

The results of this study are in line with several other studies: First, a study conducted by Anak Agung Ngurah Bagus Dhermawan I Gde Adnyana Sudibya I Wayan Mudiartha Utama, entitled The Effect of Motivation, Work Environment, Competence, and Compensation on Job Satisfaction and Employee Performance in the Office Environment Public Works of the Province of Bali which states that motivation is not significant on employee performance which means that although employees have good work motivation, it does not have a significant effect or has little effect on improving employee performance at the Bali Provincial Public Works Office.

Second, a study conducted by Harry MurtiVeronika Agustini Srimulyani (2013) with the title "The Effect of Motivation on Employee Performance with Job Satisfaction Mediation Variables at the Madiun City Pdam" states that motivation does not significantly influence employee performance.

On the other hand, the results of studies conducted by the author also refute the results of previous studies which stated that motivation has a positive and significant effect on improving employee performance, among others stated by: First, a previous study conducted by Edy Sujana (2012) which states that motivation has an effect significantly towards the organizational commitment received, the direction of its positive influence. Secondly, a previous study conducted by Rokhilah and Susetyo Darmanto (2014) stated that motivation had a positive and significant effect on the performance of family planning counselors in Pemalang Regency. Thus to improve the performance of family planning counselors in the achievement or participation of family planning it is necessary to motivate family planning counselors in Pemalang effectively. Third, a previous study conducted by Dhea Perdana Coenraad (2016) on the Influence of Ability, Motivation and Commitment on Employee Performance. This study concludes that: Motivation provides the most dominant influence on employee performance. 


\section{Influence of Commitment on the Performance of the State Civil Apparatus in terms of the Study Hypothesis, Relevant Theory}

According to Luthans (2006: 249), organizational commitment is an attitude that shows employee loyalty and is an ongoing process of how an organization member expresses their attention to the success and goodness of their organization, and in the study hypothesis (H3) it is stated that commitment has a significant effect on the performance of the State Civil Apparatus .

The results of the study showed that it was in line with the study hypothesis (H3) and Luthans' opinion that commitment had a significant positive and significant effect, when compared to the commitment variable with the value of the statistical sample $t$ test, 5.610. The following is a detailed explanation of each component in the commitment variable, as follows: First, the affective commitment component consisting of happiness and closeness or chemistry is considered important by the majority of respondents in this study, so the existence of affective commitment becomes important in improving performance State Civil parature, and the results of this study of affective commitment are in line with the opinion of Luthans (2006), which states that a strong affective commitment will continue to work in the organization because they really want to do that.

Second, the component of continuance commitment or loyalty is considered important by the majority of respondents in this study, so that the existence or according to Luthans (2006), referred to as an ongoing commitment relating to the individual's perception of the loss that will be faced if he leaves the organization. So the State Civil Apparatus will consider the profit and loss if you want to continue to join the organization or leave the organization instead.

Third, the normative commitment component is considered important by the majority of respondents in this study, so that the existence of normative commitment is the feelings of the State Civil Apparatus regarding the obligations that must be given to the organization, because these actions are the right thing to do. This means that individuals with high normative commitment will feel that they must (ought to) survive in the organization where they join (Luthans, 2006). Therefore, the entire competency component above, has a positive and significant influence in improving the performance of the State Civil Apparatus in the Population and Civil Disability Office of Situbondo Regency.

On the other hand, the results of the authors are also in line with some previous studies put forward by: First, a previous study conducted by Edy Sujana (2012) which states that organizational commitment significantly influences performance. The direction of influence is positive.

Secondly, a previous study conducted by Widi Purnama Sari (2013) stated that organizational commitment with a significance value of 0,000. Organizational Commitment has a positive and significant effect on the performance of the Civil Servants at the Pemali-Juana River Basin, meaning that if the commitment of the employee organization increases, the employee's performance will also increase.

Third, a previous study conducted by Dhea Perdana Coenraad (2016) stated that commitment affects employee performance by 70.03 percent. Other factors not examined and also influence performance are shown by the value of $\mathrm{Py}=0.2997$ or 29.97 percent. Other variables are referred to as the work environment, compensation, organizational culture, communication and so on, and fourth, a previous study conducted by Prapti Ningsih (2017) which states that commitment has a positive and 
significant effect on teacher performance in Pasangkayu District, North Mamuju Regency.

\section{Discussion of the simultaneous influence of variable $X$ together on the performance of the state civil apparatus in terms of the study hypothesis and the relevant theory}

In the study hypothesis (H4) it is stated that variable X (competence, motivation and commitment) together towards the performance of the State Civil Apparatus The hypothesis of this study is slightly different from the opinion of Griffin (1987) suggesting that performance is a result of work achieved by a person in carrying out tasks assigned to him based on skill, experience and sincerity and time, with a more detailed explanation of competence, motivation and commitment stated by expert opinion, as illustrated in the following picture:

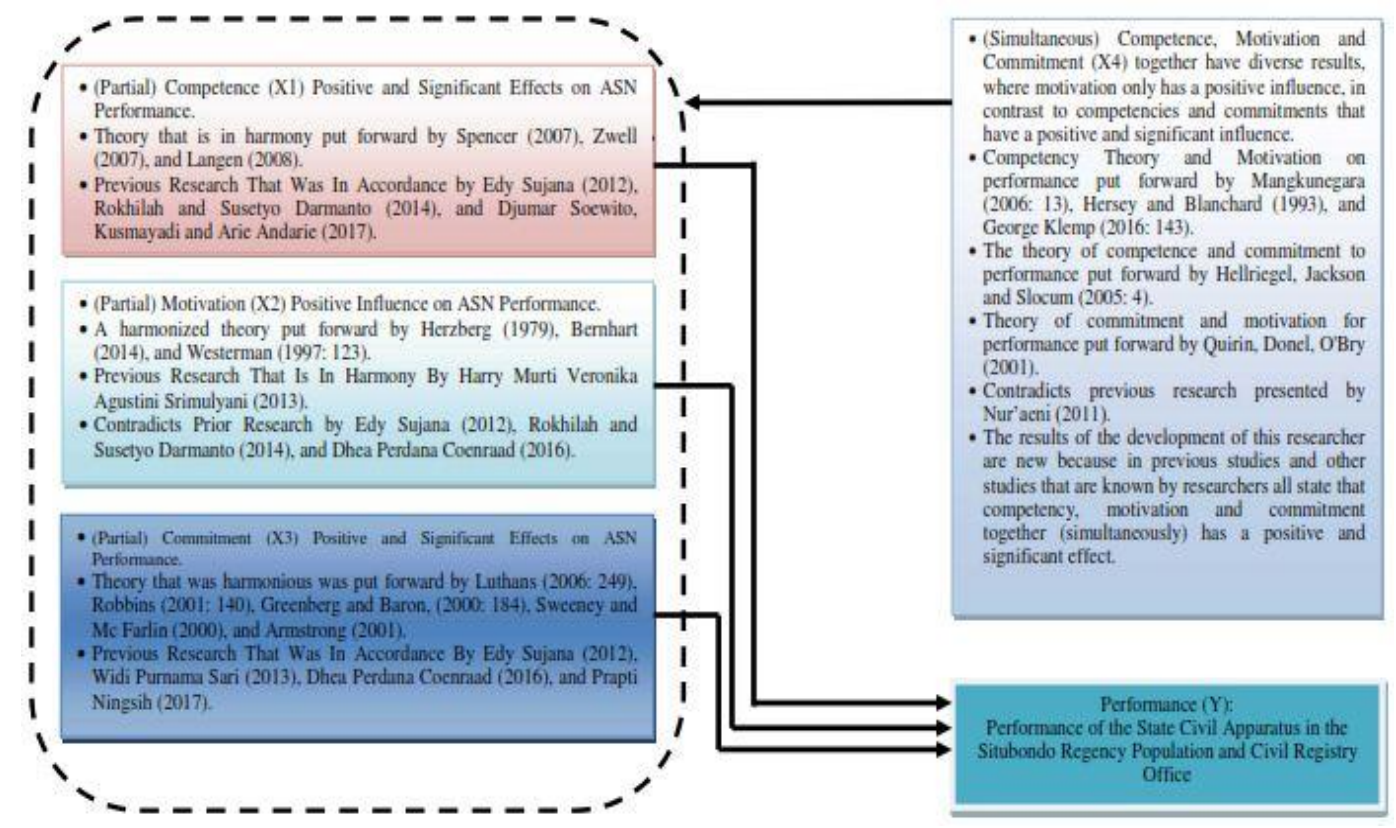

Source: Research Results

Figure 1 Research Findings

Based on the picture above, the results of this study have the meaning of novelty as the author's development, because motivation only has a positive influence. Unlike the competencies and commitments that have a positive and significant influence. The results of the development of this writer are a good progress, because in previous studies and other studies that the author knows states that competence, motivation and commitment together have a positive and significant effect.

\section{CONCLUSION}

Based on the results of the study and discussion of this thesis can be concluded, as follows:

1. Partially, competence and commitment have a positive and significant effect on the performance of the State Civil Apparatus in the Population and Disability Service Office of Situbondo Regency. While motivation has a positive effect, but it is not significant on the performance of the State Civil Apparatus in the Population and Disability Service Office of Situbondo Regency. 
2. Simultaneously the variable $X$ together on the performance of the State Civil Apparatus has different results. Where the competency and commitment variables have a positive and significant effect, whereas motivation only has a positive effect.

\section{REFERENCES}

Barnhart, Scott W. 1998. "Board composition, managerial ownership, and firm performance: An empirical analysis". The Financial Review”. 33 (November).(4).1-16.

Coenraad, Dhea Perdana. 2016. "Influence of Ability, Motivation and Commitment on Employee Performance ". Journal of Economics, Business \& Entrepreneurship Vol.10, No. 1, April 2016, Pp. 17-24.

Dhermawan, Anak Agung Ngurah Bagus, I Gde Adnyana Sudibya dan I Wayan Mudiartha Utama. 2012. "The Effect of Motivation, Work Environment, Competence, and Compensation on Job Satisfaction and Employee Performance in Bali Province Public Works Office". Journal of Management, Business Strategy, and Entrepreneurship Vol. 6, No. 2 August 2012

Irefin, Peace and Mohammed Ali Mechanic. .2014.. "Effect of Employee Commitment on Organizational Performance in Coca Cola Nigeria Limited Maiduguri”, Borno State. IOSR Journal Of Humanities And Social Science”. IOSR-JHSS. Volume 19, Issue 3, Ver. I .Mar. 2014., PP 33-4l eISSN: 2279-0837, p-ISSN: 2279-0845.bahwa terdapat hubungan yang sangat tinggi antara komitmen organisasi dan kinerja organisasi.

Decree of the Minister of Administrative Reform No. 39 of 2012 concerning Guidelines for the Development of Work Culture.

Khan M.R., Ziauddin, Jam F.A. and Ramay M.I. 2010. "The Impacts of Organizational Commitment on Employee Job Performance”. European Journal of Social Sciences. 15.3., Pp. 292-298.

Koesmono. 2005. "The Effect of Organizational Culture on Motivation and Job Satisfaction and Employee Performance in the Medium Scale Timber Processing Industry Sub Sector in East Java". Journal of Management and Entrepreneurship, Vol. 7, No. 2, September 2005: 171-188.

Kusmaningtyas, Amiartuti. 2012. "Performance of the Civil Apparatus of the Mataram City Government "Journal of Economics and Finance. Vol.1, No. 2. Pp. 487-517.

Memari, N., Mahdieh, O., Marnani, B.A. 2013. "The Impact of Organizational Commitment on Employees Job Performance "A Study of Meli Bank", Interdisciplinary Journal of Contemporary Reseach in Business Vol.5.3.:164-171.

Ningsih, Prapti. 2017. "Effect of Commitment, Competence and Work Environment on Teacher Performance in Pasangkayu District, North Mamuju Regency”. E Jurnal Katalogis, Vol. 5 No. 7, Juli 2017. Pp. 181-190. 
Regulation of the Minister of Home Affairs Number 2 of 2013 concerning Guidelines for the Development of Competency Based Education and Training Systems within the Ministry of Home Affairs and Regional Government.

Regulation of the Head of the National Personnel Agency Number 7 of 2013 concerning Guidelines for Forming Pamoedji's Managerial Competency Standards. 1986, Organizational Work. Jakarta: Bina Aksara.

Rokhilah and Susetyo Darmanto. 2014. "Influence of Competence, Motivation and Work Environment on the Performance of Family Planning Program Field Instructor (PLKB) in Pemalang Regency". Media Economics and Management Vol. 29 No. January 12014 . Pp. 68-82.

Safwan. 2014. "Effect of Competence and Motivation on Regional Financial Management Performance in the Regional Government of Pidie Jaya Regency". Accounting journal. Vol.3, No. 1. Pp. 133-139.

Sujana, Edy. 2012. "Influence of Competence, Motivation, Appropriateness of Roles and Organizational Commitment on the Performance of the Internal Auditor of the District Government Inspectorate (Study at the Badung and Buleleng Regency Inspectorate Offices). Scientific journal of Accounting and Humanika. Vol.2, No. 1. Pp. 127.

Sari, Widi Purnama. 2013. "The Effect of Work Discipline, Organizational Commitment, and the Work Environment on the Performance of Civil Servants at the Balai Pemali Juana River Basin”. Journal of Management, UDINUS. Vol. 2, No. 1. Pp. 1-12.

Soewito, Djumar, Kusmayadi, and Arie Andarie. 2017. "The Influence of Employee Competence on Employee Performance at the Sempaja Selatan Kelurahan Office in North Samarinda District". Journal of Social and Politics. Vol. 2, No. 1 Pp. 114.

Sweeney dan Mcfarlin .2000. McFarlin, D. and Sweeney, P. 2000. "Distributive and procedural justice as predictors of satisfaction with personal and organizational outcomes". Academy of Management Journal. 35 :626 - 637.

Law Number 5 of 2014 concerning State Civil Apparatus.

Law Number 14 of 2014 concerning Regional Government.

Waldman .1994. Waldman, David A. 1994. "The Contribution of Total Quality Management to a Theory of Work Performance". Academy of Management Review, Vol. 19 No.3 pp 210. 